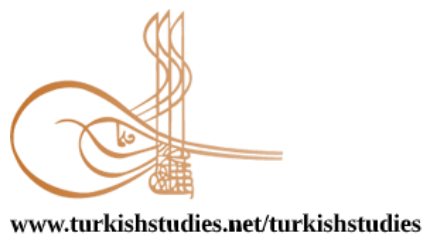

Turkish Studies

www.turkishstudies.net/turkishstudies

eISSN: $1308-2140$

TERNATIONAL

BALKAN
UNIVERSITY

Sponsored by IBU

Research Article / Araștırma Makalesi

\title{
Covid-19 Pandemisine Bağlı Yaşanan Kaygı Düzeylerinin Değerlendirilmesi: Türkiye Örneği
}

Evaluation of Anxiety Levels Arising From Covid-19 Pandemic: The Case of Turkey

Yasemin Çölgeçen* - Hasan Çölgeçen**

\begin{abstract}
The aim of this study is to determine the effects of a worldwide pandemic Covid-19 levels due to concerns experienced by individuals residing in Turkey and to evaluate anxiety in terms of various variables. The sample of the research is to form 422 individuals. In this research conducted with survey research type between 01.04.2020 and 10.05.2020, the data were collected with demographic information form and StateTrait Anxiety Inventory. Different inferential analyzes such as arithmetic mean, standard deviation, $t$ test, one way variance analysis and correlation analysis were performed in statistical operations $(\mathrm{p}<0.05)$. As a result, the process of Covid19 pandemic of individuals living in Turkey the state anxiety point average was $51.93 \pm$ 7.45 and the trait anxiety point average was $43.05 \pm 7.34$. The state-trait anxiety levels of women are higher than men, and the difference between the genders is statistically significant. It was determined that the singles had higher anxiety point average than the married ones and the difference between the groups was statistically significant in terms of trait anxiety. Anxiety levels were found to be higher than those who did not work, those who continued to work and those who work from home, and the difference between the groups was significant in terms of the level of anxiety. The difference in the mean scores of trait anxiety was found to be between those who did not continue and those who continued and did not, and those who worked from home. According to the presence of relatives diagnosed with Covid-19 infection, no significant difference was found between the groups in terms of state and trait anxiety levels. In addition, a significant and positive relationship was found between the state anxiety point averages and trait anxiety point averages. In this respect, anxiety, which can lead to more serious mental problems, is a factor that should not be ignored in order to maintain a state of spiritual well-being.
\end{abstract}

\section{Structured Abstract: Introduction:}

Covid-19, which was first detected in Hubei Wuhan, China in December, is an infection that has spread around the world very fast and that has affected over 200 countries since the first day it was detected. The speed of its transmission and spread has led Covid-19 infection to be announced as a pandemic by World Health Organisation (WHO) in 12 March, 2020. Despite the importance given to the measures taken to reduce this effect of the coronavirus, whose transmission and spread rate is very fast compared to other viral infections encountered today and to provide the treatment of people with coronavirus infection, determining the mental

* Dr. Öğr. Üyesi, Yalova Üniversitesi, İnsan ve Toplum Bilimleri Fakültesi, Sosyal Hizmet Bölümü

Asst. Prof. Dr., Yalova University, Faculty of Humanities and Social Sciences, Social Work

ORCID 0000-0002-8989-9360

akarcayasemin@gmail.com

*** Arş. Gör., Yalova Üniversitesi, İktisadi ve İdari Bilimler Fakültesi, Çalışma Ekonomisi ve Endüstri İlişkileri Bölümü

Res. Asst., Yalova University, Faculty of Economics and Administrative Sciences, Labour Economics and Industrial Relations

ORCID 0000-0002-3359-1092

hasancolgecen@gmail.com

Cite as/ Atıf: Çölgeçen, Y. \& Çölgeçen, H. (2020). Covid-19 pandemisine bağlı yaşanan kaygı düzeylerinin değerlendirilmesi: Türkiye örneği, Turkish Studies, 15(4), 261-275. https://dx.doi.org/10.7827/TurkishStudies.44399

Received/Geliş: 22 June/Haziran 2020

Accepted/Kabul: 27 August/Ağustos 2020

Checked by plagiarism software

Copyright $(\mathrm{C}$ MDE, Turkey

Published/Yayın: 30 August/Ağustos 2020

CC BY-NC 4.0 
health needs of people affected by this pandemic has been relatively neglected. Anxiety, post-traumatic stress symptoms, suicide and health anxiety are among the psychological effects of the epidemic, as experienced in previous epidemics and as seen in studies. Factors such as job losses, social isolation, increase of mortality rates, getting away from the routine of life and not performing religious rituals increase the rate of anxiety during this process. Therefore, the effects of anxiety may cause mental problems that will last for a long time.

In this respect, the subject of the study is to draw attention to the problems that may turn into psychological cases in order to ensure complete well-being during the pandemic process in which priority is given to physical well-being.

\section{Method}

Therefore it is aimed to measure the level of anxiety in this part of the research process using statetrait anxiety scale in order to determine their level of anxiety experienced in Turkey and examine individual and social sense, in terms of some variables. This scale was developed by Spielberger and his colleagues (1964). The scale that consists of 40 questions in total was adapted into Turkish by Öner and Le Compte (1983). State anxiety is the anxiety felt by the individuals participating in the study under the stressful situation they were in. Constant anxiety is the tendency of the individuals participating in the study to experience anxiety regardless of their situation. The study was conducted between 01.04.2020 and 10.05.2020. The data were analysed by using SPSS 25.0 programme. 422 participants who gave feedback to the questionnaire contributed to the study. The study was found ethically appropriate in accordance with the decision taken by the Yalova University Social Sciences Ethics Committee on 13.04.2020 (number no: 16).

\section{Findings and Discussion}

When the findings were evaluated, it was found that the state anxiety score average of participants residing in Turkey during Covid-19 pandemic process was $51.93 \pm 7.45$, while the average constant anxiety scores were found to be $43.05 \pm 7.34$. The average state anxiety is above the average of constant anxiety; and this is related to the feeling experienced under the current restricted / stressful situation. Information and news about the Covid-19 pandemic; can be counted among the possible reasons for this.

During the Covid-19 pandemic process, it has been claimed that women are more resistant when sickness and death rates were higher in men. However, when the gender and state and constant anxiety levels of individuals were evaluated, it was observed that the state-constant anxiety score levels were higher in women.

The difference between genders is statistically significant in terms of state and constant anxiety score levels $(\mathrm{p}<0,05)$. Although women are considered less physically affected during the pandemic process in the light of the data, it has been observed that they are more fragile in terms of psychological resilience.

During the Covid-19 pandemic process, single individuals living in Turkey has a higher average anxiety scores and the difference between groups is statistically significant in terms of constant anxiety $(p<0,05)$. As a result, the hypothesis "there is a significant difference in constant anxiety levels between married and single people" was supported.

Due to the Covid-19 pandemic, many workplaces had to slow down / stop production, and workers in these workplaces had to take unpaid leave, some were laid off. In this process, within the framework of their social policies, the state provided 1000 lira of aid to individuals who took unpaid leave and remained unemployed. Situations such as anxiety due to economic reasons caused by being unemployed, the risk of contamination due to participation in social life due to continuing work can increase the anxiety level of individuals. In order to determine this situation, when the state and constant anxiety levels of the participants were evaluated according to whether they continue to work or not, it was determined that the average state anxiety and constant anxiety scores of those who did not continue to work were higher than those who continued to work and those who worked from home. The constant anxiety score averages of those who continue to work are at the lowest level compared to the other groups. The average state anxiety score of those working from home is lower than the other groups. The difference between the groups in terms of constant anxiety is striking. The difference in constant anxiety score averages is those who do not continue to work, those who continue to work and those who do not work and those who work from home.

The presence of individuals infected in their immediate environment during the pandemic process can be considered among the factors that can increase the anxiety rate. In this regard, when the state and constant 
anxiety levels of the participants were evaluated according to the presence of relatives diagnosed with Covid19 infection, no significant difference was found between the groups. The main reason for this can be seen as the low number of people diagnosed with Covid-19 infection in the relatives of the individuals surveyed.

As a result of the correlation analysis conducted to determine the degree of the relationship between the state anxiety mean scores and the constant anxiety mean scores, a significant and positive relationship between constant anxiety and state anxiety mean average of the individuals living in Turkey during the Covid19 pandemic process have been found $(r(422)=, 47, p<.05)$.

\section{Conclusion and Suggestions}

A limited and quantitative study was designed to evaluate the level of anxiety experienced during the Covid-19 pandemic process; and the result generally met the expectation. The search for the answers to the factors underlying the anxiety in terms of variables is left as a suggestion for possible research and studies. Another recommendation would be to determine that supporting quantitative research methodology with qualitative research methodology will provide a more detailed perspective.

Anxiety, which can lead to more serious mental problems and its social reflection as violence, is a factor that should never be ignored. In this regard, taking into account that in addition to the physical health problems experienced during the Covid-19 pandemic process, the cost of neglecting psychological and social health will be painful and heavy, a team of professionals should be established as a precaution; a holistic approach should be adopted even when the problem is identified, diagnosed / treated, precautions and publicized. At the very beginning of the process, the scientific discourse of the boards consisting entirely of medical scientists triggered anxiety as well as benefit. The terrifying treatment over the age of sixty-five in parks, subway, and social media needs to be considered. The primary means of preventing social anxiety is to appeal to the perception level of the society. Then, it is the determination of other factors that support the increase in anxiety. We hope our research will shed light on those who are concerned about this issue.

Keywords: Social Psychology, Covid-19 Infection, Pandemic, Anxiety, State Anxiety, Trait Anxiety

Öz: Bu çalışmanın amacı tüm dünyada etkisini gösteren Covid-19 pandemisi nedeniyle Türkiye'de ikamet eden bireylerin yaşadıkları kaygı düzeylerini belirlemek ve çeşitli değişkenler açısından kaygıyı değerlendirmektir. Araştırmanın örneklemini 422 birey oluşturmaktır. 01.04.2020- 10.05.2020 tarihleri arasında tarama araştırma türü ile gerçekleştirilen bu araştırmada veriler demografik bilgi formu ve DurumlukSürekli Kaygı Envanteri ile toplanmıştır. İstatistiksel işlemlerde aritmetik ortalama, standart sapma, t testi, tek yönlü varyans analizi ve korelasyon analizi gibi farklı çıkarımsal analizler yapılmıştır $(p<0.05)$. Sonuç olarak Covid-19 pandemi sürecinde Türkiye'de yaşayan bireylerin durumluk kaygı puan ortalaması $51,93 \pm 7.45$, sürekli kaygı puan ortalamalasının ise 43,05 \pm 7,34 olduğu görülmüştür. Kadınların durumluk-sürekli kaygı düzeyleri erkeklere oranla daha yüksek olup, cinsiyetler arasındaki fark istatistiksel olarak anlamlıdır. Bekarların evli olanlara göre daha yüksek kaygı düzeyine sahip olduğu ve gruplar arasındaki farkın sürekli kaygı açısından anlamlı olduğu belirlenmiştir. İşe devam etmeyenlerin, işe devam edenlere ve evden çalışanlara göre kaygı düzeylerinin daha yüksek olduğu tespit edilmiş olup, sürekli kaygı düzeyi açısından gruplar arasındaki fark anlamlıdır. Sürekli kaygı puan ortalamalarındaki farklılığın, işe devam etmeyenler ile işe devam edenler ve işe devam etmeyenler ile evden çalışanlar arasında olduğu bulunmuştur. Covid-19 enfeksiyonu teşhisi konulan yakınlarının varlığına göre durumluk ve sürekli kaygı düzeyleri açısından gruplar arasında anlamlı bir fark bulunamamıştır. Ayrıca durumluk kaygı puan ortalamaları ile sürekli kaygı puan ortalamaları arasında anlamlı ve pozitif yönde bir ilişki bulunmuştur. Bu bakımdan daha ciddi ruhsal sorunlara yol açabilen kaygı ruhsal iyilik halinin sağlanması için gözardı edilmemesi gereken bir etmendir.

Anahtar Kelimeler: Covid-19 Enfeksiyonu, Pandemi, Kayg1, Durumluk Kayg1, Sürekli Kayg1

\section{Giriş}

Çin'de Hubei Wuhan kentinde ilk olarak aralık ayında tespit edilen Covid-19 tüm dünyaya hızlı bir şekilde yayılmış ve tespit edildiği ilk günden bu yana 200'ün üzerinde ülkeyi etkilemiş bir enfeksiyondur. Bulaşma ve yayılma hızı Dünya Sağlık Örgütü (WHO)'nün 12 Mart 2020'de Covid19 enfeksiyonunu bir pandemi olarak ilan etmesine sebep olmuştur. Covid-19 enfeksiyonu solunum 
semptomları, ateş, yorgunluk, kuru öksürük, nefes darlığı ile karakterize olan ve ağır vakalarda ise ağır akut solunum yolu enfeksiyonu, pnömoni, böbrek yetmezliği ve ölümlere sebep olabilen dünyanın son yıllarda karşılaştığı en büyük tehditlerden birisidir (WHO 2020). 15 Haziran 2020 tarihi itibari ile tüm dünyayı etkileyen bu pandemi 7 milyon 761 bin 609 kişiye bulaşmış, 430 bin 241 kişinin ise ölümüne sebep olmuştur (WHO, 2020, https://www.who.int/). Türkiye'de ise ayn1 tarihte 179 bin 831 kişi etkilenmiş, 4 bin 825 kişi hayatını kaybetmiştir (covid19.saglik.gov.tr).

Dünyada neredeyse etkilemediği ülke kalmayan ve her geçen gün ölüm sayısının artmasına sebebiyet veren yeni tip Covid-19 enfeksiyonu pek çok ülkede sosyal ve kültürel faaliyetlerin iptal edilmesine sebep olmuştur. Dünya genelinde tüm ülkeler koronavirüsün yayılma hızını azaltmak için pek çok önlem almışlardır. Bunların bazıları Türkiye'de de uygulanmış olan, uluslararası uçuşların iptal edilmesi, yüz yüze eğitime ara verilmesi, uzaktan eğitim, önemli organizasyonların iptali belirli dönemlerde sokağa çıkma yasağı uygulaması, bazı işyerlerinde evde çalışma uygulamasına geçilmesi veya esnek çalışma uygulaması, ibadethanelerde ibadete ara verilmesi, sosyal mesafe kuralının sık sık hatırlatılması ve maskesiz sokağa çıkmanın yasaklanması gibi önlemlerdir (Ayittey et. al., 2020).

Bulaşma ve yayılma hızı günümüzde rastlanan diğer viral enfeksiyonlara oranla oldukça hızlı olan koronavirüsün bu etkisini azaltmaya ve koronavirüs enfeksiyonu olan insanların tedavisini sağlamaya yönelik alınan önlemlere büyük önem verilmesine rağmen bu pandemiden etkilenen insanların ruhsal sağlık ihtiyaçlarını belirlemek nispeten ihmal edilmiştir (Xiang et al., 2020). Hastalanan ve ölen insanların sayısında her geçen gün meydana gelen artış ve salgının uzun süre devam etmesi büyük ekonomik kayıplara ve yüksek bir psikososyal riske yol açmaktadır (PAHO/WHO, 2009). Daha önceki salgınlarda deneyimlendiği ve yapılan çalışmalarda da görüldüğü üzere, anksiyete, travma sonrası stres belirtileri, intihar ve sağlık kaygısı salgının psikolojik etkileri arasında yer almaktadır (Lee, 2020: 393; Wheaton et al.,2012: 210; Wu et al., 2009: 302). Çin (2020)'de yapılan bir çalışmada, sağlık çalışanları ve COVID-19 ile enfekte olmuş hastalar arasında yüksek depresyon, travma sonrası stres, anksiyete ve uykusuzluk seviyeleri rapor edilmiştir (Lai et al., 2020). ABD (2020)'de 775 yetişkin üzerine gerçekleştirilen bir araştırmada ise, coronavirüs korkusu ve kaygısı yaşayan bireylerin sosyal tutumlarının önemli ölçüde değiştiği gözlemlenmiştir (Lee, 2020: 399). Farklı ülkelerde yaşayan bireylerin Covid-19 enfeksiyonu karşısında tutumları farklı olsa da bu süreçte meydana gelen iş kayıpları, sosyal izolasyon, ölüm oranlarının artması, yaşam rutininden uzaklaşmak, dini ritüellerin yerine getirilememesi gibi etkenler yapılan çalışmalarda da gözlemlendiği üzere kaygı oranını arttırmaktadır. Kaygı nesnesi bilinen bir duruma karşı duyulan tasalanma, endişe duygusudur. Çok hafif gerginlik duygusundan, panik derecesine varabilen yoğunluklarda olabilir. İleri derecelerinde kişinin benliği bu ruhsal acı karşısında çaresiz kalır ve kimi kez kendini toparlayamayacak duruma gelir (Ö̈ztürk ve Uluşahin, 2011: 67). Dolayısıyla kaygının etkileri uzun süre devam edecek ruhsal sorunlara neden olabilecektir.

İnsanların bir hastalığı algılayış biçimi ile hastalık karşısında verdiği tepkiler ve hastalığa uyum arasında ilişki olduğu bilinmektedir (Hekler et al., 2008). Pandemi ilk çıktığı günden itibaren insanlar üzerinde, ölüm, yoğun bakımdaki hasta ve entübe hasta sayısındaki fazlalık gibi durumlar ve medyadaki yapılan yorumlar sebebiyle korku, panik, endişe, güvensizlik gibi duygusal/tepkisel sorunların arttığı gözlenmiştir (Lai et al., 2020). Bu gibi durumlar pandeminin psikososyal etkilerininde yabana atılmaması gerektiğini gösterir. Bu bakımdan çalışmanın konusu tam bir iyilik halinin biyolojik, psikolojik ve sosyal yönlerden bütüncül bir yaklaşımla sağlanabileceği tespitinden hareketle önceliğin fiziksel iyilik haline verildiği pandemi sürecinde psikolojik vakaya dönüşmesi muhtemel sorunlara dikkat çekmektir. Bu sebeple durumluk-sürekli kaygı envanteri kullanılarak bu süreçte Türkiye'de bireysel ve toplumsal manada yaşanan kaygı düzeylerini belirlemek ve bazı değişkenler açısından incelemek amaçlanmıştır.

$\mathrm{Bu}$ değişkenler COVID-19 ile ilişkili olası kaygıdaki beş olası durumu ve farklılığı araştırmak için alanyazın taraması neticesinde belirlenmiştir. 
Birincisi erkeklerin kadınlara oranla daha fazla enfekte olduğu ve ölüm oranlarının daha fazla olduğu tespiti paylaşılmıştır. (TC. Sağlık Bakanlığı, 2020: 4-6). Bu durum defaten en resmi ağızlardan muhtelif medya aracılığıyla halka da duyurulmuştur. Bu duyuruların muhatap kitle de ne gibi bir karşı1ık bulduğu/bulacağı hususu sorgulanacaktır.

İkincisi; evli olup olmama ile kaygı düzeyleri arasında ilişki değerlendirilecektir. Pandeminin bekar bireylerde mi, evli çiftlerde mi daha çok kaygıya sebep olduğunu belirlemek amacıyla medeni durum özelinde değerlendirilecektir.

Üçüncüsü pandemi sürecinde pek çok sektörde üretim gerilemiş durmuş ve işgücü piyasasında daralmaya gidilmiştir. Bunun yanında işe devam ediyor olmanın yan etkileri; toplumsal hayata katılımın getireceği bulaş riski ve bu ikileminin kaygı düzeyini nasıl etkilediği değerlendirilecektir.

Dördüncüsü çevresinde enfekte olmuş bireylerin varlığı; sağlıklı bireyin bakışını ve kaygı düzeyini etkileyip/etkilemediği değerlendirilecektir.

Son olarak; pandemi sürecinde oluşan kaygı durumu ile sürekli kaygı düzeyleri arasındaki olumlu/olumsuz ilişki vasatı değerlendirilecektir.

Türkiye'de yaşayan bireylerin Covid-19 pandemisine bağlı yaşanan kaygı düzeylerini belirlemek ve çeşitli değişkenler açısından ilişkiyi inceleyen bu çalışmanın hipotezleri aşağıda yer alan tabloda görülmektedir:

\begin{tabular}{ll}
\hline Hipotez 1 & $\begin{array}{l}\text { Cinsiyetler arasında durumluk ve sürekli kaygı düzeyleri açısından anlamlı farklılık } \\
\text { vardır. }\end{array}$ \\
\hline Hipotez 2 & Evli ve bekarlar arasında sürekli kaygı düzeyleri açısından anlamlı farklılık vardır. \\
\hline Hipotez 3 & $\begin{array}{l}\text { Covid-19 pandemisi nedeni ile ișe devam etme durumuna göre kaygı düzeyleri } \\
\text { açısından anlamlı farklılık vardır. }\end{array}$ \\
\hline Hipotez 4 & $\begin{array}{l}\text { Çevresinde Covid-19 enfeksiyonu teşhisi konulan yakının bulunup bulunmaması } \\
\text { arasında durumluk ve sürekli kaygı düzeyleri açısından anlamlı farklılık vardır. }\end{array}$ \\
\hline Hipotez 5 & $\begin{array}{l}\text { Durumluk kaygı ile sürekli kaygı düzeyleri arasında anlamlı ve pozitif yönde bir } \\
\text { ilișki vardır. }\end{array}$ \\
\hline
\end{tabular}

\section{Yöntem}

\section{Araştırmanın Amacı}

Bu çalışmanın amacı, pandemi sürecinde Türkiye'de yaşayan bireylerin kaygı düzeylerini belirlemek ve bazı değişkenler açısından incelemektir.

\section{Araştırmanın Yöntemi}

Bu çalışma Türkiye'de yaşayan bireylerin Covid-19 pandemisi sürecinde kaygı düzeylerinin belirlenmesi ve çeşitli değişkenler açısından incelenmesini amaçlayan tarama araştırma türü ile gerçekleştirilmiştir. Sosyal bilimlerde yaygın olarak kullanılan ve büyük gruplar ile çalışmaya olanak sağlayan tarama çalışmaları geçmişte ya da halen var olan bir durumun betimlenmesini amaçlayan ve evreni temsil eden bir örneklem ile gerçekleştirilen araştırmalardır (Karasar, 2012, 79). Tarama araştırmalarının temel veri toplama tekniklerinden biri anketlerdir. Bu çerçevede çalışmada önceden geçerliği ve güvenirliği saptanmış ölçekler kullanılmıştır. Yalova Üniversitesi Sosyal Bilimler Etik Kurul Başkanlığı tarafından 13.04.2020 tarihinde (sayı no:16) alınan karar gereği çalışma etik açıdan uygun bulunmuştur. 


\section{Evren ve Örneklem}

Çalışma Türkiye'de yaşayan ve araştırmaya katılmaya gönüllü olan bireylerle yapılmıştır. Veri toplama aracı olarak online anket kullanılmıştır. Araştırma kapsamında 422 kişiye ulaşılmıştır.

\section{Veri Toplama Araçları}

Araştırma kapsamında anksiyete düzeylerini ölçmek amacıyla durumluk-sürekli kaygı ölçeği kullanılmıştır. Bu ölçek Spielberger ve arkadaşları (1964) tarafindan geliştirilmiştir. Toplamda 40 sorudan oluşan bu ölçek, Öner ve Le Compte (1983) tarafindan Türkçeye uyarlanmıştır. Ölçek Durumluk ve Süreklilik kaygı ölçekleri olmak üzere iki bölümden oluşmaktadır. Bu ölçekler 20'şer sorudan oluşan ve 4'lü likert tipi ölçeklerdir. Ölçeklerde doğrudan ve ters kodlanmış maddeler bulunmaktadır. Ters kodlanmış maddeler doğrudan kodlanan maddelerin aksine olumlu duyguları içermektedir. Durumluk kaygı ölçeğinin 10 tane ters kodlanmış maddesi $(1,2,5,8,10,11,15,16$, 19 ve 20. maddeler) vardır. Sürekli kaygı ölçeğinin ise 7 tane ters kodlanan maddesi $(21,26,27,30$, 33, 36 ve 39. maddeler) bulunmaktadır. Bu ölçeklerden toplanan puan değeri 20 ile 80 arasında değişebilmektedir. Puan büyüdükçe kaygı seviyesi artmakta puan azaldıkça kaygı seviyesi azalmaktadır (Öner \& Le Compte, 1985; Spielberger, 2010).

Durumluk Kayg 1 Ölçeği; çalışmaya katılan bireylerin içinde bulunduğu stresli durum altında hissettiği kaygıdır. Genellikle geçici bir duruma bağlı olarak gelişmektedir. Dolayısıyla strese ve gerginliğe neden olan bu durum ortadan kalktı̆̆ında olumsuz duygular ortadan kalmaktadır (Öner, 1997)

Süreklilik Kayg1 Ölçeği ise; çalışmaya katılan bireylerin içinde bulunduğu durumdan bağımsız olarak kaygı yaşamaya olan yatkınlığıdır. Kişinin içinde yaşadığı durumu çoğunlukla stresli ve gergin olarak algılama ve hissetme eğilimi olarak da ifade edilebilir (Öner, 1997).

Çalışma. 01.04.2020- 10.05.2020 tarihleri arasında gerçekleştirilmiştir. Elde edilen veriler SPSS 25.0 programı ile analiz edilmiştir. Veriler değerlendirilirken normal dağılıma uygunluğunu araştırmak amacıyla "Kolmogorov Smirnov Testi" uygulanmış ve bu test sonucunda basıklık ve çarpıklık değerleri -1 ile +1 aralığının içinde kaldığı için tüm verilerin normal dağılıma uyduğu tespit edilmiştir (Hair et al., 2013; George \& Mallery, 2010). İkili değişkenlere yönelik karşılaştırmalarda $\mathrm{t}$ testi, çoklu değişkenlere yönelik karşılaştırmalar ise tek yönlü varyans analizi (post hoc olarak Tukey testi)" ile yapılmış, sayısal değişkenler arasındaki ilişkiyi tespit etmek için ise Pearson Korelasyon Analizi kullanılmıştır. İstatistiksel olarak anlamlılık düzeyi " 0.05 " olarak değerlendirilmiş, ortalamalar aritmetik ortalama, standart sapma ile gösterilmiştir.

\section{Bulgular}

\section{Güvenilirlik Analizi}

Güvenilirlik bir ölçeğin veya testin ölçülmek istenen kavramı tutarlı ve istikrarlı bir biçimde ölçebilmesidir. Güvenilir bir ölçek veya test farklı durumlarda (yer, zaman vs.) ve farklı örneklemlere uygulandığında benzer sonuçlar verir. Bir test veya ölçeğin güvenilirliği değerlendirmek için çeşitli yöntemler kullanılmaktadır. Bunlardan birisi içsel tutarlılık analizidir. İçsel tutarlılığın ölçümünde en fazla kullanılan yöntem ise alfa katsayısıdır. Bu çalışmada Cronbach alfa güvenilirlik değeri kullanılmıştır. Cronbach alfa değeri 0 ile 1 arası değerler alır ve bu değerin en az 0.7 olması istenir (Altunış1k vd., 2010: 122-124; Gürbüz \& Şahin, 2018: 155-157).

Tablo 1: Değişkenlere Ait Güvenilirlik Rakamları

\begin{tabular}{lcc}
\hline & Cronbach's alpha & Madde sayısı \\
\cline { 2 - 3 } Durumluk Kaygı &, 859 & 20 \\
\hline Sürekli Kaygı &, 831 & 20 \\
\hline
\end{tabular}


Tablo 1'de yer aldığı üzere, Durumluk Kaygı Ölçeğinin güvenilirlik düzeyi ,859, Sürekli Kayg1 Ölçeğinin güvenilirlik düzeyi de ,831 olarak bulunmuştur. Her iki ölçeğin Cronbach Alfa değeri, kabul edilebilir düzey olan, 70'i aştığı için güvenilirlikleri doğrulanmıştır.

\section{Demografik Bulgular}

Araştırmada demografik bulgular kapsamında, cinsiyet, yaş, medeni durum, eğitim durumu, işe devam etme durumu ve çevrede hastalığa yakalanan bireyin bulunup bulunmama durumları incelenmiştir. Bu bulgulara tablo 2'de yer verilmiştir.

Tablo 2: Demografik Bulgular

\begin{tabular}{|c|c|c|}
\hline Cinsiyet & Frekans & Yüzde \\
\hline Kadın & 269 & 63,7 \\
\hline Erkek & 153 & 36,3 \\
\hline Toplam & 422 & 100 \\
\hline \multicolumn{3}{|l|}{ Yaş } \\
\hline 20 yaş altı & 12 & 2,8 \\
\hline $21-30$ & 173 & 41,0 \\
\hline $31-40$ & 138 & 32,7 \\
\hline $41-50$ & 49 & 11,6 \\
\hline $51-60$ & 37 & 8,8 \\
\hline 60 yaş üstü & 13 & 3,1 \\
\hline Toplam & 422 & 100 \\
\hline \multicolumn{3}{|l|}{ Medeni Durum } \\
\hline Evli & 220 & 52,3 \\
\hline Bekar & 201 & 47,7 \\
\hline Toplam & 421 & 99,8 \\
\hline \multicolumn{3}{|l|}{ Eğitim Durumu } \\
\hline İlköğretim & 18 & 4,26 \\
\hline Lise & 53 & 12,55 \\
\hline Önlisans & 29 & 6,87 \\
\hline Üniversite & 250 & 59,24 \\
\hline Lisansüstü & 72 & 17,06 \\
\hline Toplam & 422 & 100 \\
\hline \multicolumn{3}{|l|}{ İşe Devam Etme Durumu } \\
\hline Evet & 120 & 28,4 \\
\hline Hayır & 137 & 32,5 \\
\hline Evden Çalışıyorum & 165 & 39,1 \\
\hline Toplam & 422 & 100 \\
\hline \multicolumn{3}{|l|}{$\begin{array}{l}\text { Çevresinde Covid-19 Teşhisi Konulan } \\
\text { Bulunmakta mı? }\end{array}$} \\
\hline Evet & 52 & 12,3 \\
\hline Hayır & 370 & 87,7 \\
\hline Toplam & 422 & 100 \\
\hline
\end{tabular}

Araştırmaya dahil olan 422 katılımcının \%63,7'si kadın, \%36,3'ü erkektir. Yaş dağılımları değerlendirildiğinde \%2,8'inin 20 yaş altı, \%41'inin 21-30 yaşları arasında, \%32,7'sinin 31-40 yaşları arasında, \%11,6'sının 41-50 yaşları arasında, \%8,8'inin 51-60 yaşları arasında ve \%3,1'inin ise 60 yaş üstünde olduğu görülmüştür. Araştırmaya katılanların \%52,3'ü evli, \%47,7'si bekardır. Eğitim durumlarında ise \%4,26 ilköğretim, \%12,55 lise, \%6,87 önlisans, \%59,24 Üniversite, 17,06 lisansüstü mezunudur. Araştırmaya katılanların \%28,4'ü pandemi sürecinde işe devam etmektedir, 
$\% 32,5$ işe devam etmemekte ve çalışmamaktadır. \%39,1'i ise bu süreçte evden çalışmaktadır. Çevresinde covid-19 enfeksiyonu teşhisi konulan yakını bulunan katılımcılar \%12,3, herhangi bir yakını bulunmayan katılımcılar ise $\% 87,7$ 'dir.

\section{Durumluk ve Sürekli Kaygı Düzeylerine İlişkin Bulgular}

Tablo 3: Ölçeklerin Tanımlayıcı İstatistikleri

\begin{tabular}{lcccc}
\hline Değişken & Ortalama & $\begin{array}{c}\text { Standart } \\
\text { Sapma }\end{array}$ & Minimum & Maksimum \\
\hline $\begin{array}{l}\text { Durumluk } \\
\text { Kaygı }\end{array}$ & 51,93 & 7,45 & 36,00 & 78,00 \\
\hline Sürekli Kaygı & 43,05 & 7,34 & 23,00 & 70,00 \\
\hline
\end{tabular}

Tanımlayıcı istatistik sonuçlarına bakıldığında durumluk kaygı ortalamasının 51,93 \pm 7.45 , sürekli kayg1 ortalamasının 43,05 $\pm 7,34$ olduğu görülmektedir. Durumluk kaygı ortalaması sürekli kayg1 ortalamasından daha yüksektir. 2002 yılında 143 sağlık personeli ile gerçekleştirilen bir çalışmada durumluk kaygı ortalaması $40.57 \pm 4.88$, sürekli kaygı ortalaması ise $44.88 \pm 5.97$ bulunmuştur. Öntürk ve arkadaşlarının (2019) müsabaka öncesi 748 tekvandocuyu kapsadığ çalışmalarında da durumluk kayg1 ortalaması, sürekli kaygı ortalamasından yüksek bulunmuştur (Öntürk vd., 2019: 3764). Farklı olarak bazı çalışmalarda ise sürekli kaygı ortalamasının durumluk kaygı ortalamasına göre daha yüksek olduğu tespit edilmiştir (Ocaktan vd., 2002: 23; Başaran vd., 2009: 536; Karabulut vd., 2013: 246).

Tablo 4: Cinsiyete Göre Kaygı Düzeyi

\begin{tabular}{lcccccc}
\hline \multirow{2}{*}{ Değişken } & \multicolumn{5}{c}{ Cinsiyet } & \\
\cline { 2 - 6 } & \multicolumn{3}{c}{ Kadın } & \multicolumn{4}{c}{ Erkek } & p \\
\cline { 2 - 6 } & $\mathbf{N}$ & $\bar{x}$ & $\mathbf{N}$ & $\bar{x}$ &, 000 \\
\hline $\begin{array}{l}\text { Durumluk } \\
\text { Kaygı }\end{array}$ & 269 & 53,17 & 153 & 49,75 &, 000 \\
\hline $\begin{array}{l}\text { Sürekli } \\
\text { Kaygı }\end{array}$ & 269 & 44,13 & 153 & 41,15 & \\
\hline
\end{tabular}

Cinsiyete göre kaygı düzeyleri açısından farklılık olup olmadığını tespit etmek için yapılan bağımsız değişkenler $\mathrm{t}$ testi neticesinde Tablo 4' te yer alan sonuçlar elde edilmiştir. Analiz sonuçlarına göre kadınların durumluk kaygı düzeyi ve sürekli kaygı düzeyi erkeklere göre daha yüksek olup, cinsiyetler arasındaki farkın durumluk kaygı ve sürekli kaygı düzeyleri açısından istatistiksel olarak anlamlı olduğu belirlenmiştir $(\mathrm{p}<0,05)$. Bu sonuçlara göre $\mathrm{H} 1$ hipotezi desteklenmiştir.

Alanyazında pek çok çalışmada da kadınların kaygı düzeylerinin erkeklere göre daha yüksek olduğu belirlenmiştir. Vanderbij ve arkadaşlarının (2003) 310 kişiye yönelik gerçekleştirilen çalışmalarında kadınların durumluk-sürekli kaygı düzeylerinin erkeklere göre daha yüksek olduğu belirlenmiştir. Benzer şekilde Kaya ve Varol (2004)'un üniversite öğrencilerine yönelik çalışmalarında ise kız öğrencilerin durumluk ve sürekli kaygı düzeylerinin erkek öğrencilere göre daha yüksek olduğu ve sürekli kaygı düzeyi açısından anlamlı bir fark olduğu tespit edilmiştir. Farklı olarak sağlık çalışanlarına yönelik yapılan bir çalışmada ise erkeklerin durumluk kaygı düzeyi daha yüksek bulunurken kadınların sürekli kaygı düzeylerinin daha yüksek bulunmuştur (Vanderbij vd., 2003: 86; Kaya ve Varol, 2004: 45; Gökçe ve Dündar, 2008: 27).

Tablo 5: Medeni Duruma Göre Kayg1 Düzeyi

\begin{tabular}{|c|c|c|c|c|c|}
\hline \multirow[t]{3}{*}{ Değişken } & \multicolumn{4}{|c|}{ Medeni Durum } & \multirow[b]{3}{*}{$\mathbf{p}$} \\
\hline & \multicolumn{2}{|c|}{ Evli } & \multicolumn{2}{|c|}{ Bekar } & \\
\hline & $\mathbf{N}$ & $\bar{x}$ & $\mathbf{N}$ & $\bar{x}$ & \\
\hline Durumluk Kaygı & 220 & 51,60 & 201 & 52,28 & ,348 \\
\hline Sürekli Kaygı & 220 & 42,01 & 201 & 44,25 & ,002 \\
\hline
\end{tabular}


Medeni duruma göre kaygı düzeyleri açısından farklılık olup olmadığını tespit etmek için gerçekleştirilen bağımsız değişkenler $t$ testi neticesinde Tablo 5 ' te ki sonuçlar elde edilmiştir. Analiz sonuçlarına göre bekar olanların durumluk kaygı düzeyi ve sürekli kaygı düzeyi evli olanlara göre daha yüksek olup, gruplar arasındaki farkın sürekli kaygı açısından istatistiksel olarak anlamlı olduğu belirlenmiştir $(\mathrm{p}<0,05)$. Bu sonuçlara göre $\mathrm{H} 2$ hipotezi desteklenmiştir.

Medeni durum açısından gerçekleştirilen çalışmalar değerlendirildiğinde, benzer şekilde Karaoğlu ve arkadaşlarının (2009) aile hekimleri üzerine yaptığı çalışmalarında da da bekar olanların kaygı düzeylerinin evli olanlara göre daha yüksek olduğu tespit edilmiştir. Arslan ve arkadaşlarının hastalara yönelik çalışmalarında da bekar olanların daha yüksek kaygı düzeyine sahip olduğu tespit edilmiştir (Karaoğlu vd., 2009: 121; Arslan vd., 2017: 19).

Tablo 6: Covid-19 Pandemisi Nedeni ile İşe Devam Etme Durumuna Göre Kaygı Düzeyi

\begin{tabular}{|c|c|c|c|c|c|c|c|}
\hline \multirow[t]{3}{*}{ Değiş̧ken } & \multicolumn{6}{|c|}{ Covid-19 Pandemisi Nedeni ile İşe Devam Edip Etmeme Durumu } & \multirow[b]{3}{*}{$\mathbf{p}$} \\
\hline & \multicolumn{2}{|c|}{$\begin{array}{c}\text { Evet } \\
\text { (İşe devam ediyor) }\end{array}$} & \multicolumn{2}{|c|}{$\begin{array}{c}\text { Hayır } \\
\text { (İșe devam etmiyor) }\end{array}$} & \multicolumn{2}{|c|}{ Evden Çalışıyor } & \\
\hline & $\mathbf{N}$ & $\bar{x}$ & $\mathbf{N}$ & $\bar{x}$ & $\mathbf{N}$ & $\bar{x}$ & \\
\hline Durumluk Kaygı & 120 & 52,29 & 137 & 52,32 & 165 & 51,33 & 426 \\
\hline Sürekli Kaygı & 120 & 42,07 & 137 & 44,69 & 165 & 42,40 &, 006 \\
\hline
\end{tabular}

Katılımcıların pandemi sürecinde işe devam edip etmeme durumlarına göre kaygı düzeyleri açısından farklılık olup olmadığını belirlemek için gerçekleştirilen tek yönlü varyans analizi neticesinde tablo 6'da görülen sonuçlara ulaşılmıştır. Analiz sonuçlarına göre işe devam etmeyenlerin durumluk kaygı ve sürekli kaygı düzeyleri işe devam edenlere ve evden çalışanlara göre daha yüksektir. İşe devam edenlerin sürekli kaygı düzeyleri diğer gruplara göre en düşük seviyede iken evden çalışanların durumluk kaygı düzeyi diğer gruplara oranla daha düşük seyretmektedir. Sürekli kaygı düzeyi açısından gruplar arasındaki fark anlamlıdır. Gruplar arasındaki farklılığın hangisinden kaynaklandığını belirlemek için Tukey HSD testi yapılmıştır. Sürekli kaygı düzeyi ortalamalarındaki farklılığın işe devam etmeyenler ile işe devam edenler ve işe devam etmeyenler ile evden çalışanlar arasında olduğu görülmüştür.

Tablo 7: Çevrede Covid-19 Teşhisi Konulan Yakının Varlığına Göre Kaygı Düzeyleri

\begin{tabular}{lccccc}
\hline Değişken & \multicolumn{4}{c}{ Çevrede Covid-19 Teşhisi Konulan Yakının Varlı̆̆ } & \\
\cline { 2 - 5 } & \multicolumn{3}{c}{ Evet (Var) } & \multicolumn{3}{c}{ Hayır (Yok) } & p \\
\cline { 2 - 6 } & $\mathbf{N}$ & $\overline{\boldsymbol{x}}$ & $\mathbf{N}$ & $\overline{\boldsymbol{x}}$ & ,742 \\
\hline Durumluk Kaygı & 52 & 52,25 & 370 & 41,71 &, 159 \\
\hline Sürekli Kaygı & 52 & 51,88 & 370 & 43,24 & \\
\hline
\end{tabular}

Katılımcıların çevrelerinde hastalığa yakalanan bireylerin varlığına göre kaygı düzeyleri açısından herhangi bir farklılık bulunup bulunmadığını değerlendirmek amacıyla yapılan bağımsız değişkenler t testi neticesinde Tablo 7' de ki sonuçlara ulaşılmıştır. Analiz sonuçlarına göre çevresinde hastalığa yakalanan bireyler bulunan katılımcıların durumluk kaygı düzeyi daha yüksek bulunurken, sürekli kaygı düzeyi çevresinde hastalığa yakalanan bireyin olmadığı katılımcılara göre daha düşük düzeyde bulunmuştur. Gruplar arasındaki fark istatistiksel olarak anlamlılık göstermemektedir $(\mathrm{p}<0,05)$. Bu sonuçlara göre $\mathrm{H} 3$ hipotezi desteklenmemiştir.

Durumluk kaygı ve sürekli kaygı düzeylerinin arasındaki ilişkinin derecesini belirlemek amacıyla korelasyon analizi gerçekleştirilmiştir. Analiz sonuçları 0.05 güvenilirlik katsayısına göre değerlendirilmiştir. 
Tablo 8: Durumluk Kaygı ve Sürekli Kaygı Değişkenleri Arası Korelasyon Katsayıları

\begin{tabular}{cccc} 
& & Durumluk Kaygı & Sürekli Kaygı \\
\hline Pearson Korelasyon & Durumluk Kaygı & 1,000 &, 476 \\
& Sürekli Kayg1 &, 476 & 1,000 \\
\hline Sig. & Durumluk Kaygı & $\cdot$ &, 000 \\
& Sürekli Kayg1 &, 000 &. \\
\hline N & Durumluk Kayg1 & 422 & 422 \\
& Sürekli Kayg1 & 422 & 422 \\
\hline
\end{tabular}

Tablo 8.'de yer verilen analiz neticelerine göre katılımcıların durumluk kaygı ortalamaları ile sürekli kaygı ortalamaları arasında anlamlı ve pozitif yönde bir ilişki bulunmaktadır $(r(422)=$ ,47, $p$ <.05). Değişkenler arasında pozitif ilişki, durumluk kaygının artması ile sürekli kaygının da arttığı anlamına gelmektedir. Bu sonuçlar H4 hipotezinin desteklendiğini göstermektedir.

\section{Bulguların Tartışması}

Bu çalışma, dünyayı etkisi altına alan Covid-19 pandemisi sürecinde Türkiye'de yaşayan bireylerin kaygı düzeylerini muhtelif değişkenler açısından inceleme/değerlendirme amacı gütmektedir.

Covid-19 pandemi sürecinde Türkiye çapında kısıtlı imkanlar içinde yaptığımız kısmi çalışma neticesinde hastalık karşısında bireylerin durumluk kaygı puan ortalamas $151,93 \pm 7.45$, sürekli kayg1 puan ortalaması ise 43,05 7,34 olarak tebarüz etmiştir. Gürüldüğü gibi durumluk kayg1 ortalaması sürekli kaygı ortalamasından daha yüksekte seyretmektedir. Durumluk kaygı içinde bulunulan stresli durum altında hissedilen kaygı türüdür. Bu bakımdan durumluk kaygı puanının sürekli kaygı puanına göre daha yüksek olmasının sebebi tüm dünyayı etkisi altına alan pandemidir.

Covid-19 pandemi sürecinde bilim kurulu üyeleri ile medya daha hastalığın ilk aylarında erkeklerin kadınlara oranla daha fazla enfekte olduğu hatta vefat ettiği bilgisini dillendirmiştir. Bu haber ve bilgilendirmeye muhatap olan erkeklerin mi yoksa kadınların mı daha fazla/yoğun kayg1 taşıdığı/yaşadığ 1 hususuna bir 1 şık tutması amacıyla gerçekleştirilen analiz neticesinde durumluk/sürekli kaygı puan düzeylerinin beklenenin aksine kadınlarda daha yüksek olduğu ve cinsiyetler arasındaki farkın durumluk kaygı ve sürekli kaygı puan düzeyleri açısından istatistiksel olarak anlamlı olduğu görülmüştür. ( $\mathrm{p}<0,05)$. Maaravi ve Heller (2020)'de Birleşik Krallık'ta 407 kişiye yönelik gerçekleştirdiği çalışmada da bu süreçte kadınların daha fazla kaygı yaşadığ 1 tespitinde bulunmuştur. (Maaravi\& Heller, 2020: 243-244). Tayvan'da Wong ve arkadaşlarının (2020) 3555 kişiye yönelik yaptıkları çalışmayla da aynı sonuca ulaşılmıştır (Wong et al., 2020: 4). Pandemi sürecinin dışında da alanyazında pek çok araştırma/çalışma bu tespiti paylaşmıştır (Vanderbij vd., 2003: 86; Kaya ve Varol, 2004: 45).

Covid-19 pandemi sürecinde medeni durum baz alınarak durumluk ve sürekli kayg1 düzeyleri ele alındığında bekar olanların evli olanlara göre daha yüksek kaygı puan ortalamasına sahip olduğu hatta gruplar arasındaki farkın sürekli kaygı açısından istatistiksel olarak anlamlı olduğu belirlenmiştir $(p<0,05)$. Hacimusalar ve arkadaşlarının (2020) 2156 kişi üzerine gerçekleştirdikleri çalışmada pandemi sürecinde evlilerin bekarlara göre daha fazla durumluk kayg1 puan ortalamasına sahip oldukları, bekarların ise evlilere göre daha fazla sürekli kaygı puan ortalamasına sahip olduğu tespitini paylaşmıştır (Hacimusalar, 2020: 184). Pandemi süreci dışında da pek çok araştırma/çalışma bu tespiti desteklemektedir (Karaoğlu vd., 2009: 121; Arslan vd., 2017: 19).

Pandemi sürecinde işe devam edip etmeme durumuna göre durumluk ve sürekli kayg1 düzeyleri değerlendirildiğinde işe devam etmeyenlerin durumluk kaygı ve sürekli kaygı puan ortalamalarının işe devam edenlere ve evden çalışanlara göre daha yüksek olduğu tespit edilmiştir. İşe devam edenlerin sürekli kaygı puan ortalamaları ise diğer gruplara göre en düşük seviyededir.

Turkish Studies, 15(4) 
Evden çalışanların durumluk kaygı puan ortalamaları diğer gruplara oranla daha düşük seyretmektedir. Pandemi sürecinde çalışmaya evden devam ediyor olmak bulaş riskini azaltması ve işsizlik riskinin olmaması bakımından bireylerin daha az kaygı yaşamasını sağlamıştır. Sürekli kaygı düzeyi açısından gruplar arasındaki fark anlamlıdır. Sürekli kaygı puan ortalamalarındaki farklılık, işe devam etmeyenler ile işe devam edenler ve işe devam etmeyenler ile evden çalışanlardır. İşe devam etmeyenlerin yaşadıkları gelir kaybı, gelecek endişesi sürekli kaygı puan ortalamalarının yüksek olmasına sebep olmaktadır.

Katılımcıların çevrelerinde Covid-19 enfeksiyonu teşhisi konulan yakınlarının bulunup bulunmadığına göre durumluk ve sürekli kaygı düzeyleri değerlendirildiğinde gruplar arasında anlamlı bir fark bulunamamıştır. Bunun sebebinin yakınlarında Covid-19 enfeksiyonu teşhisi konulan kişi sayısının az olmasına bağlı olduğu düşünülmektedir.

Türkiye'de yaşayan bireylerin durumluk kaygı ortalamaları ile sürekli kaygı ortalamaları arasında anlamlı ve pozitif yönde bir ilişki bulunmuştur $(r(422)=, 47, p<.05)$. Değişkenler arasında pozitif ilişki, durumluk kaygının artması ile sürekli kaygının da arttığı anlamına gelmektedir. Alanyazında pandemi sürecinde olsun ya da olmasın yapılan pek çok çalışma da benzer sonuçlara ulaşılmıştır (Coşkun vd., 2011: 1127).

\section{Sonuç ve Öneriler}

Covid-19 pandemisi sürecinde 'ilk dalga' olarak da ele alınan evre de her geçen gün hastalığa yakalandığı tespit edilen ve vefat eden insan sayısı artmaktadır. Pek çok ülke yayılımı önlemek için önlemler yürürlüğe koymuş; günlük rutinlerde olağandışı kısıt ve değişime gidilmiş; bunlar da nice ekonomik ve psikososyal riske davetiye çıkarmıştır. Bu bakımdan çalışmamız tüm dünyayı etkiliyen süreçte Türkiye'de yaşayan farklı statü ve cinsiyetten bireylerin kaygı düzeylerini tespiti; çeşitli değişkenler açısından değerlendirilmesi amacına yönelik olmuştur. Sürecin gereği alınan önlemlere bağlı kısıtlı ve kaygılı olduğu öngörülen pek çok bireye bilimsel katkı ricası ve online anket aracılığı ile ulaşılmıştır. Araştırmaya, ankete dönüt veren 422 birey katkı sağlamış ve bu veriler belli ölçekler dahilinde analiz edilmiştir.

Türkiye'de ikamet eden bireylerin covid-19 pandemi sürecinde durumluk kayg1 puan ortalamalarının 51,93 \pm 7.45 , sürekli kaygı puan ortalamalarının ise 43,05 $\pm 7,34$ olduğu tespit edilmiştir. Durumluk kaygı ortalaması sürekli kaygı ortalamasının üstündedir; bu da içinde bulunulan kısıtl1/stresli durum altında yaşanan hissiyatla ilişkilidir. Covid-19 pandemisi ile ilgili yapılan bilgilendirme ve haberler; bunun olas1 sebepleri arasında sayılabilir.

Covid-19 pandemi sürecinde Türkiye'de hastalık ve vefat oranları erkeklerde daha yüksek seyredince; kadınların daha dayanıklı oldukları iddiası dillendirilmiştir. Ancak bireylerin cinsiyetleri ve durumluk ile sürekli kayg1 düzeyleri değerlendirildiğinde durumluk-sürekli kayg1 puan düzeylerinin kadınlarda daha yüksek olduğu gözlenmiştir. Cinsiyetler arası fark; durumluk ve sürekli kaygı puan düzeyleri açısından istatistiksel olarak anlamlıdır $(\mathrm{p}<0,05)$. Netice olarak "cinsiyetler arasında durumluk ve sürekli kaygı düzeyleri açısından anlamlı farklılık var" hipotezi kabul edilmiştir. Her ne kadar kadınlar veriler ışığında pandemi sürecinde fiziksel olarak daha az etkilenen cinsiyet olarak kabul edilse de psikolojik sağlamlık açısından daha kırılgan olduğu gözlemlenmiştir.

Covid-19 pandemi sürecinde Türkiye'de yaşayan bireylerin evli/bekar olma durumlarına göre durumluk ve sürekli kaygı düzeyleri değerlendirildiğinde bekarların daha yüksek kaygı puan ortalamasına sahip olduğu ve gruplar arasındaki farkın sürekli kaygı açısından artışı istatistiksel olarak anlamlıdır. $(\mathrm{p}<0,05)$. Netice olarak "evli ve bekarlar arasında sürekli kaygı düzeyleri açısından anlamlı farklılık var" hipotezi desteklenmiştir.

Covid-19 pandemisi nedeni ile pek çok işyeri üretimi yavaşlatmak/durdurmak zorunda kalmış, bu işyerlerinde çalışan işçiler ise ücretsiz izne ayrılmak zorunda kalmış, bazıları ise işten çıarılmıştır. Devlet bu süreçte ücretsiz izne ayrılan ve işsiz kalan bireylere sosyal politikaları 
çerçevesinde 1000 lira yardım gerçekleştirmiştir. İşsiz kalmanın meydana getirdiği ekonomik sebeplere bağlı oluşan endişe, işe devam etme sebebiyle toplumsal hayata katılımın getireceği bulaş riski gibi durumlar bireylerin kaygı düzeyini arttırabilmektedir. $\mathrm{Bu}$ durumu tespit amaciyla katılımcıların işlerine devam edip etmeme durumuna göre durumluk ve sürekli kaygı düzeyleri değerlendirildiğinde işe devam etmeyenlerin durumluk kaygı ve sürekli kaygı puan ortalamalarının işe devam edenlere ve evden çalışanlara göre daha yüksek olduğu tespit edilmiştir. İşe devam edenlerin sürekli kaygı puan ortalamaları ise diğer gruplara göre en düşük seviyededir. Evden çalışanların durumluk kaygı puan ortalamaları diğer gruplara oranla daha düşük seyretmektedir. Sürekli kaygı düzeyi açısından gruplar arasındaki fark dikkat çekicidir. Sürekli kaygı puan ortalamalarındaki farklılık, işe devam etmeyenler ile işe devam edenler ve işe devam etmeyenler ile evden çalışanlardır. Netice olarak "Covid-19 pandemisi nedeni ile işe devam etme durumuna göre kaygı düzeyleri açısından anlamlı farklılık var" hipotezi desteklenmiştir.

Pandemi sürecinde yakın çevresinde enfekte olan bireylerin varlığı kaygı oranını arttırabilecek etkenler arasında sayılabilir. Hem yakınını kaybetme endişesi hem de kendisi dahil yakın çevresine bulaş riskini düşünmek kaygı düzeyini etkileyecektir. Bu bakımdan katılımcıların çevrelerinde Covid-19 enfeksiyonu teşhisi konulan yakınlarının bulunup bulunmadığına göre durumluk ve sürekli kaygı düzeyleri değerlendirildiğinde gruplar arasında anlamlı bir fark bulunamamıştır. $\mathrm{Bu}$ durumda "çevresinde Covid-19 enfeksiyonu teşhisi konulan yakının bulunup bulunmaması arasında durumluk ve sürekli kaygı düzeyleri açısından anlamlı farklılık var" hipotezi dayanak bulmamıştır. Bunun başlıca sebebi ankete katılan bireylerin yakınlarında Covid-19 enfeksiyonu teşhisi konulan kişi sayısının azlığı olarak görülebilir.

Durumluk kaygı puan ortalamaları ile sürekli kaygı puan ortalamaları arasındaki ilişkinin derecesini belirlemek amaciyla yapılan korelasyon analizi neticesinde Covid-19 pandemi sürecinde Türkiye'de yaşayan bireylerin durumluk kaygı ortalamaları ile sürekli kaygı ortalamaları arasında anlamlı ve pozitif yönde bir ilişki bulunmuştur $(r(422)=, 47, p<.05)$. Değişkenler arasında pozitif ilişki, durumluk kaygının artması ile sürekli kaygının da arttığı anlamına gelmektedir. Bu sonuçlara göre "Durumluk kaygı ile sürekli kaygı düzeyleri arasında anlamlı ve pozitif yönde bir ilişki var" hipotezi desteklenmiştir.

Covid-19 pandemisi sürecinde yaşanan kaygı düzeyini değerlendirmek amacıyla sınırlı ve nicel bir araştırma tasarlanmış; sonuç genel olarak beklentiyi karşılamıştır. Değişkenler açısından kaygının altında yatan etmenlerin cevabının aranması ise yapılması muhtemel araştırma ve çalışmalara bir öneri olarak bırakılmıştır. Diğer bir tavsiyemiz ise nicel araştırma metadolojisinin nitel araştırma metadolojisi ile desteklenmesinin daha ayrıntılı bir bakış açısı kazandıracağı tespiti olacaktır.

Daha ciddi ruhsal sorunlara yol açabilen ve toplumsal yansıması şiddet şeklinde yansıyabilen kayg1 asla gözardı edilmemesi gereken bir etmendir. Bu bakımdan Covid-19 pandemisi sürecinde yaşanan fiziksel sağlık sorunlarının yanında psikolojik ve sosyal sağlı̆̆ ihmal etmenin faturasının da acı ve ağır olacağı göz önüne alınarak önlem olarak öncelikle ilgili uzmanlardan oluşan profesyonellerin birarada bulunduğu bir ekip kurulmall; sorunun tespiti, teşhisi/tedavisi, önlemler ve halka duyurulmasın da bütüncül yaklaşım sergilenmelidir. Malum insanın ilk veri toplama duyusu kulak pek çok şeyi önce işiterek algılamışız. Aynı haberi sunuş/ifade tarzı muahatap olan insanda iki ayrı duygu durumunu oluşturabilmektedir. Ne söyleyeceğimiz kadar, ağzımızdan çıkandan halk kitlelerinin ne gibi manalar çıkarabileceği de hesap edilmelidir. Aksi takdirde birilerini hele belli yaşın üstündekilere dışlama hatta afaroz etme eylemine dönüşebilir. Süreç başlarında yanlış haber sunum, enini boyuna hesap etmeden yapılan bilgilendirme neticesi hiçte hak etmedikleri halde altmışbeş yaş üstü bireylere takınılan tutum gösterilen tepki/muamele çoğumuzu incitti, yürekleri burktu değil mi? 
Toplumsal ve bireysel endişeyi/kaygıyı tetikleyen unsurlar arasında internet medyacıllı̆̆, aspragas haber, sorumsuz gazetecilik/televizyonculuk sayılabilir. Ancak bunların tümünden daha etkin olanı tetkili/bilimsel ağızlardan çıkanlardır. Şuyu vuku'undan beter deyimi tam da buna işaret eder. Organik/fiziksel kaynaklı hastalıkların takibi/kontrolü ruhi/psikolojik olana göre daha kolaydır. Yani kaygının yol açabileceği tahrip hastalıktan daha tesirli olacaktır. Bunun için en az bilimsel yöntemlerle hastalık ve araza çare arandığı kadar bireysel kaygıyı tespit/teşhis edip bertaraf edilmesine yönelik tedbirler üretilmelidir. Sürecin daha başlangıcında tamamen tıp bilim adamlarından oluşan kurulların bilimsel söylemleri yarar ürettiği kadar kaygıyı da tetiklemiştir. Altmışbeş yaş üstüne parklarda, metroda, sosyal medyada reva görülen ürkütücü muamele üzerinde düşünülmesi gerekir. Toplumsal kaygının önüne geçme yollarının başta geleni toplumun algı düzeyine hitap edebilmektir. Sonrası ise kaygı artı̧ını destekleyen diğer faktörlerin tespitidir. Araştırmamızın bu işi kendine dert edinenlere ışı tutacağını umuyoruz.

\section{Kaynakça}

Altunışık, R., Coşkun, R., Bayraktaroğlu, S. ve Yıldırım, E. (2010). Sosyal Bilimlerde Araştırma Yöntemleri SPSS Uygulamalı. Sakarya Yayıncılık.

Arslan, S., Taylan, S. ve Deniz, S. (2017). Nöroşirürji Hastalarının Ameliyat Öncesi Anksiyete Düzeyleri, Anadolu Hemşirelik ve Sağlık Bilimleri Dergisi, 20(1): 17-21. https://doi.org/10.26559/mersinsbd.288773

Ayittey, F. K., Ayittey, M. K., Chiwero, N. B. Kamasah, J. S. and Dzuvor, C. (2020). Economic Impacts of Wuhan 2019-nCoV on China and the World, Journal of Medical Wirology, 1-3. 10.1002/jmv.25706. https://doi.org/10.2139/ssrn.3669016

Başaran, M. H., Taşğın, Ö., Sanioğlu, A. ve Taşkın, A. K. (2009). Sporcularda Durumluk ve Sürekli Kayg1 Düzeylerinin Bazı Değişknelere Göre İncelenmesi, Selçuk Üniversitesi Sosyal Bilimler Enstitüsü Dergisi, 21: 533-542. https://doi.org/10.9775/kausbed.2018.011

Coşkun, K., Şahan, A. ve Erman, K. A. (2011). Üniversite öğrencilerinin durumluluk kayg1 düzeyinin tenis sınav performansı üzerine etkisinin incelenmesi, Uluslararası İnsan Bilimleri Dergisi, 8(1): 1121-1130.

Gökçe, T. ve Dündar, C. (2008). Samsun Ruh ve Sinir Hastalıkları Hastanesi'nde Çalışan Hekim ve Hemşirelerde Şiddete Maruziyet Sıklığı ve Kaygı Düzeylerine Etkisi, İnönü Üniversitesi Tıp Fakültesi Dergisi, 15 (1): 25-28. https://doi.org/10.14235/bs.2018.1709

Gürbüz, S. ve Şahin, F. (2018). Sosyal Bilimlerde Araştırma Yöntemleri Felsefe Yöntem Analiz, Seçkin Yayıncılık.

Hacimusalar, Y., Kahve, A. C., Yasar, A. B. and Aydin, M. S. (2020). Anxiety and hopelessness levels in COVID-19 pandemic: A comparative study of healthcare professionals and other community sample in Turkey. Journal of Psychiatric Research, 129: 181-188. https://doi.org/10.1016/j.jpsychires.2020.07.024

Hekler, E.B., Lambert, J., Leventhal, E., Levethal, H., Jahn, E. and Contrada R.J. Commonsense İllness Beliefs, Adherence Behaviors and Hypertension Control Among African Americans. Journal of Behavioral Medicine, Vol.31, 2008, 391-400. https://doi.org/10.1007/s10865008-9165-4

TC. Sağlik Bakanlığ1 (2020), https://covid19.saglik.gov.tr (Erişim Tarihi: 15.06.2020)

WHO (2020), https://www.who.int/docs/default-source/coronaviruse/mental-healthconsiderations.pdf 

WHO (2020), https://www.who.int/emergencies/diseases/novel-coronavirus-2019?gclid $=$ Cj0KCQjwuJz3 BRDTARIsAMg-HxXRYc-axDMfB5Z4xv2NAXXL8XnPuP7q AqEBkOBPXqb3 WsiDzUECtmQaAmYsEALw_wcB.

WHO (2020), https://www.who.int/health-topics/coronavirus. (Erişim Tarihi 17.03.2020)

Karabulut, E. O., Atasoy, M., Kaya, K. ve Karabulut, A. (2013). 13-15 Yaş Arası Erkek Futbolcuların Durumluk ve Sürekli Kaygı Düzeylerinin Farklı Değişkenler Bakımından İncelenmesi, Ahi Evran Üniversitesi Kırşehir Ĕgitim Fakültesi Dergisi (KEFAD), 14(1): 243-253. https://doi.org/10.19171/uefad.679322

Karaoğlu, N., Bulut, S., Baydar, A. ve Carelli, F. (2009). Aile Hekimlerinde Durumluk ve Sürekli Anksiyete Düzeyi: Bir Vaka Kontrol Çalışması, Türk Aile Hek Derg, 13(3): 119-126. https://doi.org/10.2399/tahd.09.119

Karasar, N. (2012). Bilimsel araştırma yöntemi. Nobel Yayıncılık.

Kaya, M. ve Varol, K. (2004). İlahiyat Fakültesi Öğrencilerinin Durumluk-Sürekli Kaygı Düzeyleri ve Kaygı Nedenleri (Samsun Örneği), Ondokuz Mayls Üniversitesi Ilahiyat Fakültesi Dergisi, 17(17): 31-63. https://doi.org/10.16950/iujad.346615

Lai, J., Ma, S., Wang, Y., Cai, Z., Hu, J., Wei, N., ... Hu, S. (2020). Factors associated with mental health outcomes among health care workers exposed to coronavirus disease 2019, JAMA Network Open, 3(3), 1-12. doi: 10.1001/ jamanetworkopen.2020.3976. https://doi.org/10.1001/jamanetworkopen.2020.3976

Lee, S. A. (2020). Coronavirus Anxiety Scale: A Brief Mental Health Screener for COVID-19 Related Anxiety, Death Studies, 44:7, 393-401. https://doi.org/10.1080/07481187.2020.1748481

Maaravi, Y. \& Heller, B. (2020). Not All Worries Were Created Equal: The Case of COVID-19 Anxiety, Public Health 185: 243-245. https://doi.org/10.1016/j.puhe.2020.06.032

Ocaktan, M. E., Keklik, A. ve Çöl, M. (2002). Abidinpaşa Sağlık Grup Başkanlığı'na Bağlı Sağlık Ocaklarında Çalışan Sağlık Personelinde Spielberger Durumluk ve Sürekli Kaygı Düzeyi, Ankara Üniversitesi Tlp Fakültesi Mecmuast, 56(1): 21-28. https://doi.org/10.1501/tipfak_0000000705

Öner, N. (1997). Türkiye'de Kullanılan Psikolojik Testler. Boğaziçi Üniversitesi.

Öner, N. and Le Compte, A. (1985). Süreksiz Durumluk Sürekli Kaygı Envanteri El Kitabı. Boğaziçi Üniversitesi Yayınları, İstanbul, 1-26.

Öntürk, Y., İmamoğlu, O. ve Karacabey, K. (2019). Elit Tekvandocularda Durumluk ve Sürekli Kaygının Araştırılması, Manas Sosyal Araştırmalar Dergisi, 8 (4): 3764-3774. https://doi.org/10.33206/mjss.541990

Öztürk, O. ve Uluşahin, A. (2011). Ruh Sağlı̆̆ı ve Bozuklukları, Nobel Tıp Kitabevi (Yenilenmiş 11. Bask1).

Spielberger, C. D. (2010). State-Trait Anxiety Inventory. The Corsini Encyclopedia of Psychology. https://doi.org/10.1002/9780470479216.corpsy0943

TC. Sağl1k Bakanlı̆̆1 (2020). Covid-19 Durum Raporu Türkiye, 30.06.2020, https://dosyamerkez.saglik.gov.tr/Eklenti/37778,covid-19-durum-raporupdf.pdf? 0\&_tag1=B647A4A46C8B41228B2C445361452762CAEFD728

Vanderbij, A. K., Weerd, S., Cikot, R. J. L., Steegers, E. A. P. ve Braspenning, J. C. C. (2003). Validation of the Dutch Short Form of the State Scale of the Spielberger State-Trait Anxiety 
Covid-19 Pandemisine Bağlı Yaşanan Kaygı Düzeylerinin Değerlendirilmesi: Türkiye Örneği 275

Inventory: Considerations for Usage in Screening Outcomes, Community Genet, 6:84-87. https://doi.org/10.1159/000073003

Wheaton, M. G., Abramowitz, J. S., Berman, N. C., Fabricant, L. E., \& Olatunji, B. O (2012). Psychological Predictors of Anxiety in Response to The H1N1 (Swine Flu) Pandemic, Cognitive Therapy and Research, 36(3), 210-218. https://doi.org/10.1007/s10608-0119353-3

WHO (2020). Situation report - 78 Coronavirus disease 2019 (COVID-19) 7 April 2020 https://www.who.int/emergencies/diseases/novel-coronavirus-2019/situation-reports/ (Erişim Tarihi 07.04.2020)

Wong, L. P., Hung, C. C., Alias, H. and Lee, T. S. (2020). Anxiety symptoms and preventive measures during the COVID-19 outbreak in Taiwan, BMC Psychiatry, 20: 376. https://doi.org/10.1186/s12888-020-02786-8

Wu, P., Fang, Y., Guan, Z., Fan, B., Kong, J., Yao, Z., Liu, X., \& Hoven, C. W. (2009). The Psychological İmpact of The SARS Epidemic on Hospital Employees in China: Exposure, Risk Perception, and Altruistic Acceptance of Risk, Canadian Journal of Psychiatry, 54, 302-311. https://doi.org/10.1177/070674370905400504 